\title{
From aspiring saint to disillusioned rebel. Explaining change in the Polish narrative of European integration
}

\section{Introduction}

On the eve of Poland's accession to the European Union (EU), on late evening of 30 April 2004 President Aleksander Kwaśniewski delivered a speech, highlighting that it was now only minutes that separated Poland from the EU: "we waited for this day. We worked hard and we can now congratulate ourselves on our regained independence and sovereignty, the founding blocks of our road to Europe [...] surely there is still a lot of work ahead of us. But we achieved so much already, we passed our Europeanness exam" (Kwaśniewski, 2004). These words provide a useful illustration of the selflabelling process that Poland and other Central-East European countries (CEEC) went through under the asymmetrical accession logic. At the end of the Cold War, these states were extremely eager to be accepted and recognized as members of the western world and thus to rapidly internalize rules and norms of multilateral organisations such as EU and NATO (Adler-Nissen, 2014). Outsiders from the former Soviet bloc felt the need to modernize and Europeanize; to "catch up" with the politically and economically "mature" and "modern" Western Europe.

The exam metaphor is both a valid and telling one, as the accession process was mostly about learning and emulating, i.e. modernization by imitation (Jasiecki, 2008), and providing justifications to the assertion that one did the homework (i.e. adequately transposed the acquis communautaire) and is now European enough to be welcome to the EU club. Thus unsurprisingly and despite fears that eastern enlargement would increase compliance deficit already existing in the EU, studies have shown that the new EU10 were complying better with the acquis than the old EU15: data suggested that virtually all the newcomers outperformed virtually all the old members during their first 4 years of membership (Sedelmeier, 2008).

The accession framework - with central role of the conditionality principle, inevitable insider/ outsider logic and differentiation of rights and obligations during lengthy transition periods even when membership had already been granted - was conducive to creating and sustaining hierarchy, while facilitating "orientalization" (Bideleux, 2015) of prospective/ new members. The result was the division of the continent into the centre that had power to define what was European ("normal"), aspiring CEEC under transformation (Europeanization) and eastern peripheries excluded from membership perspective (Grzymski, 2016). The inequality in terms of status between EU Western and Eastern members is well illustrated by the domination of discriminatory 
rather than exemptive transition periods following enlargement. An exemption meant postponing the entry into force of EU rules and standards that would be too costly to implement at the moment of accession, taking into account the level of development of the acceding state. Discriminatory differentiation temporarily deprived new members of certain rights and benefits resulting from membership, as their implementation was deemed too costly for the EU (i.e. agricultural subsidies, access to labour market). Whereas the 1973 enlargement brought mostly differentiation based on exemptions, the eastern enlargements (2004 and 2007) - mostly differentiation based on discrimination (Schimmelfennig, 2014).

Inequality was also reflected in varying degrees of recognition as to who could legitimately speak, voice claims and undertake autonomous action. When president of France Jacques Chirac famously declared back in February 2003 that the acceding CEEC "lost an opportunity to keep quiet" (fr. ont manque une bonne occasion de se taire), it became clear that for those in central (dominant) positions, the peripheral newcomers should properly behave during a "trial period" before they are recognized as fully-fledged members of the "European family."

In this article I argue that notions of (in)equality, hierarchy and status are vital to explain the evolution of Poland's official narrative of European integration and the discursive construction of Poland's place in the EU's hierarchical structure. Thus the research question is the following: how has Poland moved from narrating itself as a champion of Europeanization (strategy of adaptation) to a rebel that contests not only individual European policy solutions, but also the very foundations of the European project as it had developed post-Maastricht (strategy of contestation)?

In order to explain the evolution of the Polish government's narrative, this article conceptually draws on Pierre Bourdieu's field theory (Bourdieu, 1979; 1989; 2014) and Erving Goffman's stigma theory (Goffman, 1986[1963]) that have already inspired work on social hierarchies in international relations (Zarakol, 2011; 2017; Adler-Nissen, 2014; 2017). Accordingly, I assume that the European Union constitutes a field - a social system, where positions of member states are hierarchically structured. But this hierarchy is also being contested, especially in times of crisis (crises). Each member state strives for acceptance and status within the field. Narratives that states produce are linked to dominant or subordinate positions in the field and reflect strategies of legitimization and stigmatization that aim at reproduction or subversion of the field's rules of the game. I argue that narrative production by Polish decisionmakers reveals a marked shift in strategies adopted to deal with Poland's in-between status structured by both incomplete recognition and continuous (self-) stigmatization: from strategy of adaptation (correction) to strategy of contestation (resistance), where stigma is embraced and transformed into a virtue.

Empirically, this article draws on qualitative analysis of speech acts produced in the years 2010-2018 by prime ministers and members of government (both official and media statements). The above-mentioned shift is illustrated with examples of narrative production under 3 crises: 1) euro-zone crisis (Poland adapts to the dominant narrative and promotes its own austerity experience, while allying itself with the northern "saints" against the southern "sinners"); 2) migration crisis (Poland moves from adaptation to contestation, while narrating the "lack of solidarity" stigma as the responsible 
"normal"); 3) rule of law crisis (Poland consolidates its contestation strategy, while framing the dispute with the European Commission as a counter-measure from undemocratic EU centre to discipline "real" democrats in the periphery).

\section{Conceptualization: how to deal with Poland's in-between status in the EU field of power}

The utility of Bourdieu's sociology for analysis of international relations (IR) and European integration has been well documented in the literature: "although Bourdieu himself dedicated very little attention to international relations and European integration, his work is probably the most powerful resource we have for understanding the genesis and structure of what can be termed the European field of power" (Cohen, 2011, p. 335; Adler, 2013, p. xv). Thus Bourdieu's theory has been extensively used to analyze EU internal and external policy-making (Martin-Maze, 2015; Villumsen Berling, 2012). A major advantage of bringing his social theory into IR/ EU studies is that it allows to shed light on dynamics of vertical stratification (hierarchy) among states in the international (EU) system, allegedly characterized by anarchy ${ }^{1}$ or sovereign equality, i.e. according to EU treaties (Zarakol, 2017, p. 3). Yet, although sovereignty is a marker of equal status in multilateral fora, it does not put all states in a level playing field (Adler-Nissen, 2017).

According to Bourdieu, a field is a social system where positions of actors (in our case relevant EU member states) are hierarchically structured, for example according to centre/ periphery or established members/newcomers lines. Field is "the space between agents who possess the sufficient amount of one of the different kinds of capital to be in position to dominate the corresponding field" (Zarycki, Smoczyński, Warczok, 2017, p. 362). Hierarchy is maintained by dominant actors by means of reproduction of power structures, but it is also being contested. Theories in social sciences are embedded in one of two paradigms: a paradigm of cooperation or a paradigm of conflict. Bourdieu represents the latter and this is in stark contrast to approaches on European integration that underline (functional) cooperation. Field theory assumes inevitable emergence and existence of inequalities and social conflicts that constitute the main objects of research. Consensus is about naturalized - that is perceived as self-evident - hegemony of dominant actors (Bourdieu, 2014). It can reign as long as subordinated actors pursue strategies of adaptation and recognize the power structure as given or beneficial. It is a constant rule of the field that dominant actors (incumbents) tend to pursue strategies of conservation, whereas newcomers eventually deploy strategies of subversion (Bourdieu, 1979, p. 362; Bourdieu, 1989, pp. 372-374).

Inspired by Bourdieu, literature on hierarchies in IR deals with two basic problems: origins of hierarchy and strategies of actors dealing with hierarchy (Zarakol, 2017, p. 4). This article contributes to the later strand, while engaging with the following questions: how do actors reproduce/challenge/use existing hierarchies? How do existing hierarchies function? How do they produce compliance or resistance? It has been

${ }^{1}$ In IR studies it is widely assumed that "domestic systems are centralized and hierarchic" whereas "international systems are decentralized and anarchic" (Waltz, 2010). 
argued in the literature that hierarchies depend on constant recognition by both those that are above and below in ranking. Hierarchies are produced through interactive (and not unidirectional) processes of self- and other-labelling, where subordinate states contribute to their own subordination (Adler-Nissen, 2017). Self-labelling, resulting from anxiety about national status (what do others think about us), is just as important as discourse emerging from dominant positions in the hierarchy. Labels of "backwardness," "periphery," etc. may contribute to sustaining hierarchy as long as they are recognized by both the dominant and subordinate actors.

To be sure, production of hierarchies in the EU does not only concern the relationship between the "western" and "eastern" member states. The notion of the centre (core) is always a moving target: strategic usages of hierarchies allow for re-framing of parts of the centre as peripheries or creation of "far east" that would allow to frame the east as centre (or central - example: "Central Europe" as opposed to "Eastern Europe"). For instance, Italy's accession to the euro zone was narrated in late 1990s as a chance for modernization of Italian economy and dealing with Italy's (a founding member state!) marginalization in Europe, as Italians had continued to identify themselves and were identified by others as a "second tier" country compared to Germany, France or the UK (Guirlando, 2012; Adler-Nissen, 2017). As we will see below, this narrative is (un)surprisingly similar to the adaptive narrative Polish authorities produced during the euro zone crisis.

According to Zarakol $(2011 ; 2017)$ it is the behaviour of actors situated (trapped) "in-between" and not those in top (dominant) or bottom (subordinated) positions that is mostly affected by hierarchy. Aspiration to higher ranks makes them more vulnerable to incumbents' stigmatization, but also more likely to give up corrective strategies and respond with resistance to socialization pressures. The nature of being "in-between" may concern various aspects, such as positioning between central West (North) and peripheral East (South) or a status of middle state (power), which is neither a small player reconciled with its limitations, nor a big player with significant resources.

Status is not only about material power and is at least partly socially conferred. Normative pressure resulting from adherence to an exclusive group generates expectations about "normal" behaviour and sanctions for misbehaviour, which falls below "civilizational standards," such as - in the EU case - rule of law and liberal values. In Goffman's terms, stigmatization serves a key function in every social system. When used by dominant actors, it sustains social order by clarifying the boundaries of acceptable behaviour and identity and the consequences of non-conformity, i.e. shame, exclusion or other forms of punishment. Boundary-drawing by means of stigmatization becomes especially important in times of uncertainty and disagreement about basic norms. Stigmatizing the norm-breaker reinforces the notion of normality. Constant and explicit affirmation of norms and values is not always necessary, but the rationale for stigmatization is to identify those who actually threaten the social order. The process of stigmatization contains a number of elements, from labelling and stereotyping to separation (us versus them) and finally discrimination (Adler-Nissen, 2014). But stigma is not only suffered and internalized, it can also be actively managed despite asymmetrical power relationship between those stigmatizing and those stigmatized. Goffman identified two broad strategies of stigma management. 
The first one is about stigma recognition that results in narrating correction and adaptation in quest for social recognition from members of the club (the "normals") and identification with them. The problem with this strategy is that a newcomer, no matter how hard they try, cannot cease to be a newcomer and may become former newcomer at best (Zarakol, 2011). This means that behaviour may be corrected, but the discreditable attribute remains and may be easily used by the dominant actors whenever misconduct occurs.

The second strategy is about embracing the stigma as a blessing in disguise and to recourse to counter-stigmatization. The backwardness and peripheral status are then narrated as a virtue, whereas modernization and Europeanization become sources of trouble, insecurity and moral decay. The meaning is reversed: what has been considered normal by the centre is now framed as abnormal by the periphery. But counterstigmatization also entails an important dilemma. Transgression of rules of the game necessary to change the power structures requires manifestations of respect for existing rules of the game. Every field exerts a kind of censorship or in the words of Bourdieu - "imposition of forms:" "if you want to be recognized as philosopher you must assume certain forms in order to say things - especially if what you want to say is hostile to tacit presuppositions of the philosopher's trade" (Bourdieu, 2014, p. 58). An alternative is a "spoiler strategy," where the contesting actor "refuses to be polite, rejects the game - it is he whom the social world completely expels" (Bourdieu, 2014, p. 59).

\section{Empirical analysis: narrating adaptation, narrating contestation}

The shift in the Polish official narrative of European integration should be interpreted as a change of strategy in dealing with the stigma (real or imagined): from strategy of stigma recognition (adaptation to the existing hierarchy) to counter-stigmatization (contestation of the existing hierarchy). In line with the theoretical approach outlined above, I argue that usages of (counter-)stigmatization are particularly evident in times of crisis when uncertainty and disagreement about basic norms and values makes the affirmation of the normal more needed than ever. At the same time, crises provide opportunities for resisting and dismantling the old hierarchies. Below I look at legitimization and stigmatization processes associated with the euro zone, migration and rule of law crises and attempt to examine reproduction and reconstruction of hierarchies in the adaptive and contesting narratives of the Polish governments. Whereas the euro zone crisis enabled fading of the West-East hierarchy and marked the peak of Poland's adaptive strategy towards an image of a serious and mature member state, the migration crisis renewed the West-East division, while revealing the significant shift from adaptation to contestation, where in the Polish narrative it was now Western Europe that was irresponsible and immature when accepting migrants. Finally, the rule of law crisis provoked by the highly controversial judiciary reform in Poland consolidated the resistance strategy, while framing the dispute as a counter-measure from the undemocratic EU centre to discipline "real" democrats in the periphery. Consequently, the nar- 
rative has moved from contestation of a particular policy solution (migration quotas) to undermining normative foundations of the European integration process.

\section{Euro-zone crisis and the strategy of adaptation}

The stigmatizing acronym of PIGS, used to denote Portugal, Italy, Greece and Spain, was initially coined in the 1990s to refer to southern European economies that faced significant challenges in joining the Economic and Monetary Union (EMU). It made a comeback with the sovereign debt crisis in the late 2000s, where it was used interchangeably for Italy and Ireland or doubled (PIIGS) to account for both. Another media label was "Club Med", which referred to stereotypes of lazy and wine-drinking-underthe-sun southerners as opposed to the hard-working and frugal northerners. As stressed by Matthijs and McNamara (2015), hard work, prudent savings, moderate consumption, wage restraint, and fiscal stability in Germany were seen as northern virtues and were juxtaposed to the southern vices of low competitiveness, meagre savings, undeserved consumption, inflated wages, and fiscal profligacy in the Mediterranean.

This "us saints versus them sinners" narrative of the dominant actors (in particular Germany, but also Netherlands, Finland and other "northerners") served as legitimization tool for their preferred solution to the crisis. This solution - austerity - was to be found at the national and not at the European level, where a supranational solidarity mechanism could have been created (Matthijs, Blyth, 2015a; McNamara, 2015; Adler-Nissen, 2017). Instead, each country had to make an individual effort to return to "responsible" fiscal consolidation. The root cause of the crisis was diagnosed in excessive state spending at nation-state level that has led to unsustainable levels of debt and deficits that in turn threatened the entire euro zone (Schauble, 2011) and not in pressures on the banking system and euro zone structural imbalances that led to unsustainable debt levels in more vulnerable states (Laffan, 2016). Stigmatization of the southern "sinners" was present in articulations coming from both leaders of states and international organizations. "We're not saying that saving solves all problems, but you can't spend more than you take in. You can't live your whole life this way. Everybody knows this" (Merkel, 2012). "As far as Athens is concerned, I think about all those people who are trying to escape tax all the time" (Lagarde, 2012).

Thus to remedy the situation, the South was to be stigmatized into corrective behaviour of adaptation to and emulation of the North. This had two consequences for hierarchy production and reproduction in the EU. Firstly, the cleavage between West (centre) and East (periphery) was (temporarily) replaced with the North (centre) and South (periphery) divide. Secondly, this provided an opportunity for countries such as Poland - a euro zone outsider largely unaffected by the euro zone crisis - to strengthen its position in the EU field by allying itself with the dominant centre and promoting its own post-communist austerity experience as a success story of responsible macroeconomic policies. Strict austerity and conditionality may have come as a shock to the southern member states, but they were nothing new to the eastern members who were now able to take pride in and promote their adaptive effort of transformation and pre- 
accession Europeanization as universal solution to economic challenges. As argued by a Polish entrepreneur quoted by the Financial Times, Poland's success story is due to the fact that "workers in the rest of Europe are simply lazier [...] Poles work harder than almost anyone else in the union" (Cienski, 2012).

Thus the official narrative of the Polish government in the years 2011-2014 focused on 3 elements: a) creating the image of a shining example of responsible economic policies and growth (self-legitimization); b) willingness and ability to join the integration centre - the euro zone in the long run (further promise of adaptation); c) making sure that in short to medium term Poland is not relegated to the peripheries as a noneuro zone member and is not blamed for the European economic crisis (addressing stigma burden that may always be used against the former newcomer).

According to Polish foreign affairs minister, solutions adopted in Poland already in the 1990s (limits of debt and deficit enshrined in the Constitution) were now being adopted throughout Europe and in the EU fiscal compact. Moreover, "by 2015 we wish to fulfil all the convergence criteria to be able to adopt the euro. It is in Poland's political interest to accede to the closest circle of integration of states that have common currency" (Sikorski, 2012). It is also vital for Poland to participate in the euro-zone rescue efforts in an attempt to stay within the integration core and sustain "Europe of community method" (Tusk, 2011). As - according to the narrative - differentiation into integration circles was becoming a reality and a new European construction was emerging, it was in Poland's strategic interest to join the euro zone integration centre as soon as possible. The rationale was not only economic, but - more importantly - geopolitical (Sikorski, 2013). Accordingly, a state that continued to occupy an "inbetween" position of EU member and euro zone non-member was confronted with a choice to either join the centre or to be pushed back towards the periphery, which - according to the narrative - equalled returning to the "East" and possibly under the Russian domination.

Notwithstanding the responsible economic policies and manifest willingness to actively support the euro zone rescue efforts, the stigma (real or imagined) still induced Polish decision-makers to deny existence of any link between the crisis and enlargement. Moreover, eastern enlargement was narrated as contributing to mitigate effects of crisis in Western Europe. As stated by Sikorski in his famous Berlin speech: "let me first say what this crisis is not about. It was not caused - as some have suggested - by enlargement. Enlargement has created growth and wealth all over Europe [...] enlargement - far from causing the crisis, has arguably delayed the economic turmoil. Thanks to the advantages of trading in an enlarged market, West European welfare states have been forced to face reality only now" (Sikorski, 2011).

\section{Migration crisis and the strategy of contestation at the policy level}

In the late 2015 the eruption of migration crisis marked a shift from Poland's strategy of adaptation towards strategy of contestation. Initially, the change of government - from liberal Civic Platform to national-conservative Law and Justice - appeared not to be a game changer. On 11 November 2015 Konrad Szymański, 
designated minister for European affairs stated: "there is no legal basis allowing for withdrawal from commitments made by [Civic Platform's] Ewa Kopacz. But we will not treat [agreed relocation scheme] as a pilot project for a permanent mechanism" (Szymański, 2015a). However, 3 days later, while referring to terrorist attacks in Paris, Szymański claimed that "implementation of the decision to relocate refugees is not politically possible for Poland [...] Poland has to retain full control of its borders, asylum and migration policies" (Szymański, 2015b). In her opening speech before the parliament later that month the newly appointed prime minister Beata Szydło asserted that solidarity meant "sharing what is good and being ready to help in cases of emergency or dangerous events such as natural disasters, terrorist or military threats." But solidarity is not about "attempts to export problems that were caused by some states, without participation of other states that are now expected to carry the burden" (Szydło, 2015). While attempting to "de-Europeanize" the migration crisis and reduce it to a self-inflicted problem of one member state (Germany) at the national level, the government sought to re-interpret the notion of solidarity and re-define what should be considered as responsible "normal." This move has activated the stigmatizing "othering" from the dominant actors and made the separation between East and West re-emerge as other Central European (V4) countries sided with Poland.

President of the European Commission underlined that "solidarity is not a one-way street" (Juncker, 2016), referring to eagerness of Central Europeans to benefit from European solidarity in the form of budgetary transfers (cohesion funds) coupled with refusal to offer solidarity when others were in need. President of the European Parliament went even further, asserting the failure of Central Europeans to act responsibly and cooperate loyally: "we are not dealing with a failure of the EU, but with a glaring failure of some governments, who don't want to take responsibility and thereby impede a joint European solution" (Schulz, 2015). Whereas officials generally showed restraint, media, think-tanks and academics resorted to stigmatization more openly. For instance, it was "deeply distressing to see East European societies and governments $[\ldots]$ claiming it is morally right to shut their doors to those running from death" (Krastev, 2015). "Austrian politicians used to talk about Visegrad group with respect [...] nowadays Visegrad is like a bad word" (The Economist, 2016). There exists "obvious disparity between East and Western Europe in terms of solidarity and compassion for the people fleeing to Europe" (ECFR, 2015).

Despite domestic calls for corrective behaviour and acceptance of a limited number of asylum seekers (similarly to lip-service tactics skilfully used by many other member states), Polish government engaged in straightforward counter-stigmatization of European institutions and their supposedly reckless and irresponsible behaviour that was to directly threaten security of European citizens. According to the Polish MFA, "faced with migration crisis, the European Commission took a series of hasty and irresponsible steps" (Waszczykowski, 2016). The prime minister made a direct link between migration and terrorism: "we have been learning about a new act of terrorism every day and about more innocent people dying [...] I think that we are once again getting confirmation that the policy of the Polish government is simply proving right [contrary to the Western European ones - AKC] when it comes to migration and the diagnosis 
of the situation" (Szydło, 2016a). She also claimed that "we will not participate in the folly of the Brussels elites" (Szydło, 2016b).

As of 30 October 2018 Poland and Hungary, as only EU members, have not relocated a single refugee from Greece or Italy despite obligations under the Council legally binding decision. In December 2017 the Commission launched an infringement procedure against Poland, Hungary and Czech Republic for "non-compliance with their legal obligation on relocation." Whereas infringements of EU secondary laws are nothing new and virtually all member states have been subjected to infringement procedures before the Court of Justice in one area or another, justifications given for non-compliance by Poland provide an important case in point. Namely, the argument is that the relocation decision taken by QMV (as allowed by the treaties) should not have been taken. The fact that a legal instrument exists does not mean that it may always be used: "one needs some political rationality to be able to deny oneself this pleasure [...] this method [QMV] runs the risk of neglecting interests of some states" (Szymański, 2018, p. 39). What acceptance of this argument would mean in practice is effective abandoning of the QMV in favour of unanimity whenever a member state considers it "politically rational;" or a member state reserving itself a right to disregard any decision that has been taken by QMV despite its opposition. What is more, this reasoning is based on highly imprecise criteria of "political rationality," meaning that every single refusal to comply with legal obligations can be justified in such highly imprecise terms that hardly mask the objective of discretionary cherry-picking. This is where resistance to a specific policy solution (relocation quotas) transforms into contestation of the basic rules of the game in the EU field.

\section{Rule of law crisis and the strategy of contestation at the systemic level}

On 13 January 2016 European Commission launched the rule of law procedure against Poland in accordance with the framework defined in its communication from March 2014. As a result, the Commission issued 4 recommendations addressed to the Polish government (27 July 2016, 21 December 2016, 26 July 2017 and 20 December 2017). Lack of corrective behaviour under the rule of law framework led the Commission to launch, in parallel, infringement procedures (July 2017, July 2018 and April 2019) and two of them have already been referred to the Court of Justice (European Commission, 2019). This protracted crisis has induced the Polish government to consolidate its strategy of contestation and proceed to comprehensive counter-stigmatization of EU institutions and selected member states. There was also some minor adaptation to the Court of Justice rulings, but of largely selective and symbolic nature.

The government's representatives attempted to reframe the issue from focus on rule of law to focus on democracy, where the EU was stigmatized as "undemocratic" in contrast to the clear democratic mandate of the Polish government. Speaking in early 2016 in the European Parliament, prime minister Szydło placed the democratic mandate of her party at the heart of her argumentation: "we introduce changes [with regard to the Constitutional Court - $\mathrm{AKC}$ ], because as a result of democratic 
elections of October 2015 Polish citizens decided, in this democratic electoral act, that they wanted those changes, which had been proposed by my party, to be implemented. This is the decision of Polish citizens" (European Parliament, 2016). Thus the respect of the rule of law was weighted against the government's right to introduce virtually any change justified by the electoral victory, despite the fact that the latter only led to an absolute and not constitutional majority in the Polish parliament.

Whereas - according to this narrative - the Polish government is merely implementing policies that reflect the will of the people, the Union that tries to discipline democratically elected government of a nation-state, has itself serious problems with democracy. According to minister of foreign affairs, "democratic deficit in the EU is real and has profound political consequences [...] Growing contestation of the European integration is not the reason of EU democratic weakness, but its consequence. Nothing harms the European idea more than de facto inequality of member states before the law, double standards and the Commission moving away from its role of guardian of the treaties towards being a tool in the hands of some member states [...] Poland is an old democracy, one of the oldest in Europe" (Czaputowicz, 2018a). In line with this narrative, Poland is no longer a newcomer, but an established democratic state that resists unfair inequality reigning in the EU to the benefit of the powerful few and not to the benefit of the common good.

The villains are clearly identified in this story. They are those who claim the right to discipline and stigmatize the Polish government for not accepting the existing hierarchy, but in reality constitute a genuine threat for the European integration project: "if France has internal problems, and scolds Poland off, this is unfair. One should first clean one's own mess. This sends the wrong message, threatening Poland when there are all these problems in France. I think there is a significant threat to the rule of law in France" (Czaputowicz, 2018b). It is thus France and not Poland that is violating EU law. However, the EU employs double standards and treats Poland and France differently. Violation by France of the EU rule on maximum 3\% budgetary deficit adversely affects competition in the single market and poses a new risk of financial crisis. In view of the Polish government, the Commission accepts this situation and does not fulfil its role of guardian of the treaties (Le Figaro, 2019).

In December 2017, due to the inefficacy of the rule of law dialogue and under pressure from the European Parliament, the Commission launched - in an unprecedented move - the disciplining procedure under art. 7 TEU against Poland. This move, which so far has not led to any formal decisions or sanctions as provided by the treaty, could be interpreted in terms of dominant actors sanctioning a spoiler behaviour - a threat of expulsion from "polite society." Another example of actions aimed at disciplining spoilers is the "cordon sanitaire" employed by centre-left political groups in the European Parliament: despite impressive national victory in May 2019 European elections, the Polish ruling party was refused management positions (EP vice-president and commission chair) in a series of votes that took place in early July 2019 (Cianciara, 2019). Actions by dominant actors are aimed at rule consolidation, but are also seen by the contesting actor as further proof of discrimination and may encourage more resistance instead of adaptation. 


\section{Conclusion: what consequences for Poland's status in the EU}

Until the year 2015 subsequent Polish governments engaged in a strategy of adaptation, which has been considered the most effective way to become "normalized" as part of the EU core. It was assumed that consistent efforts to become a "saint" or "best student in class," while joining the centre of the ever more differentiated Union (Cianciara, 2014), would eventually lead to overcoming the stigma and to Poland being granted recognition and status of dominant member in the EU field of power along Germany and France. But after the 2015 parliamentary elections the narrative changed dramatically and the new Polish government engaged in a strategy of contestation, positioning itself not so much as a "sinner," but rather as a "rebel," willing to change existing rules of the game and the hierarchy in the EU field of power. The declared rationale behind the government's strategy of contestation was that existing EU power structures and further conciliatory pursuit of adaptation no longer benefited Polish national interest.

The theoretical framework outlined above informs reflection on the change of Poland's strategy and official narrative in 3 ways. First of all, it shows that systemic features of the EU field of power encourage shift from adaptation to contestation in case of actors in subordinate positions. Secondly, it indicates that outright contestation is more likely in case of "in-between" positions, i.e. actors convinced that their relatively important (and growing) resources are not matched by sufficient recognition and status in the field. Thirdly, there are two broad types of contestation available. Whereas rule transgression could be achieved when incrementally implemented and coupled with affirmation of the existing normative order, a spoiler strategy is more likely to result in rule consolidation and disciplining actions of the centre towards the periphery.

The latter adequately outlines the situation of the Polish government in mid-2019, with practically no impact on the new EU institutional set-up for the years 2019-2024, growing number of rule of law cases pending before the Court of Justice of the EU and no prospects for the annulment of the art. 7 (TEU) procedure. Return to a credible strategy of adaptation seems unlikely under the national-conservative government that stands high chances of remaining in power until 2023 at least. Together with inevitably stronger pressure on rule consolidation coming from the centre, this implies growth of conflictual dynamics within the EU at the CEEC's expense. On the other hand, exclusion (marginalization) of spoilers may work well in individual cases of isolated sinners, but proliferation of spoiler behaviour to a steadily growing number of disillusioned peripheral actors from Eastern and Southern Europe runs the risk of dismantling the existing hierarchy.

\section{Bibliography}

Adler E. (2013), Preface, in: Bourdieu in International Relations: Rethinking Key Concepts in IR, ed. R. Adler-Nissen, Routledge, London-New York.

Adler-Nissen R. (2014), Stigma Management in International Relations: Transgressive Identities, Norms, and Order in International Society, "International Organization", 68: 1. 
Adler-Nissen R. (2017), Are we 'Nazi Germans' or 'Lazy Greeks'? Negotiating Hierarchies in the Euro Crisis, in: Hierarchies in World Politics, ed. A. Zarakol, Cambridge University Press, Cambridge.

BBC News (2017), EU to sue Poland, Hungary and Czechs for refusing refugee quotas, 07.12.2017, http://www.bbc.com/news/world-europe-42270239.

Bideleux R. (2015), The "Orientalization" and "de-Orientalization" of East Central Europe and the Balkan Peninsula, "Journal of Contemporary Central and Eastern Europe", 25:1, pp. 9-44.

Bourdieu P. (1979), La distinction: critique sociale du jugement, Minuit, Paris.

Bourdieu P. (1989), La noblesse d'Etat: grandes écoles et esprit de corps, Minuit, Paris.

Bourdieu P. (2014), On the State. Lectures at the College de France 1989-1992, Polity Press, Cambridge.

Cianciara A. K. (2014), Differentiated Integration and the Future of Europe. Debate in Poland, "Yearbook of Polish European Studies", vol. 17, pp. 167-189.

Cianciara A. K. (2019), Unia skręca w lewo i na zachód?, forumIdei/Blog, Fundacja im. Stefana Batorego, 12.07.2019, http://www.batory.org.pl/forum_idei/blog_idei/agnieszka_cianciara unia_skreca_w_lewo_i_na_zachod?fbclid=IwAR11SNqUEvNGRSqDpklu3-REvRmFk1 wwrbweUc_- $90 \overline{\mathrm{SM}} \mathrm{MmpaKV} \overline{\mathrm{k}} \mathrm{k}$ Cbh0KPQ4.

Cienski J. (2012), Poland's growth defies euro zone crisis, "Financial Times", July 1, https://www. $\mathrm{ft.com} /$ content/99bb5b68-c13d-11e1-8eca-00144feabdc0.

Cohen A. (2011), Bourdieu hits Brussels: The Genesis and Structure of the European Field of Power, "International Political Sociology", 5: 3, pp. 335-339.

Czaputowicz J. (2018a), Expose 2018, 21 March 2018, https://msz.gov.pl/pl/polityka_zagraniczna/ priorytety_polityki_zagr_2017_2021/expose2/expose_2018/.

Czaputowicz J. (2018b), Francja jest chorym człowiekiem Europy, ciagnie ja $w$ dót. Natomiast Polska jest jasnym punktem, "Polsat News", 17.12.2018, http://www.polsatnews.pl/ wiadomosc/2018-12-17/francja-jest-chorym-czlowiek-europy-czaputowicz-o-ataku-wparyzu-i-protescie-zoltych-kamizelek/.

ECFR (2015), https://www.ecfr.eu/article/commentary_understanding_eastern_european_attitudes_ on_refugees 4019 .

European Commission (2019), Rule of Law: European Commission launches infringement procedure to protect judges in Poland from political control, Brussels, 3 April, http://europa.eu/ rapid/press-release_IP-19-1957_en.htm.

European Parliament (2016), Situation in Poland (debate), Strasbourg, 19.01.2016 (prime minister Beata Szydło).

Goffman E. (1986), Stigma: notes on management of spoiled identity, Touchstone Book, New York.

Grzymski J. (2016), Powrót do Europy - Polski Dyskurs. Wyznaczanie perspektywy krytycznej, Oficyna Wydawnicza Uczelni Łazarskiego, Warszawa.

Jasiecki K. (2008), The Europeanization of Polish Democracy, "Polish Sociological Review", no. 164 , pp. $359-382$.

Juncker J.-C. (2016), https://www.telegraph.co.uk/news/2016/05/26/block-migrant-quotas-and-loseeu-funding-eastern-europe-warned/.

Krastev I. (2015), https://www.nytimes.com/2015/09/09/opinion/eastern-europes-compassion-deficit-refugees-migrants.html?_r $=0$

Kwaśniewski A. (2004), Udział Prezydenta RP z Małżonka w uroczystości na Placu Piłsudskiego z okazji przystapienia Polski do Unii Europejskiej, 30.04.2004, https://www.prezydent.pl/ aleksandra-kwasniewskiego/aktualnosci/rok-2004/art,153,225, udzial-prezydenta-rp-z-malzonka-w-uroczystosci-na-placu-pilsudskiego-z-okazji-przystapienia-polski-do-unii-europejskiej.html. 
Laffan B. (2016), Core-Periphery Dynamics in the Euro Area: from Conflict to Cleavage?, in: CorePeriphery Relations in the European Union: Power and Conflict in a Dualist Political Economy, eds. J. M. Magone, B. Laffan, C. Schweiger, Routledge.

Lagarde C. (2012), https://www.theguardian.com/world/2012/may/25/payback-time-lagarde-greeks.

Le Figaro (2019), Déficit: la Pologne accuse la France de "violer la loi européenne", 04.01.2019, http://www.lefigaro.fr/flash-eco/2019/01/04/97002-20190104FILWWW00121-deficit-lapologne-accuse-la-france-de-violer-la-loi-europeenne.php.

Martin-Maze M. (2015), Unpacking Interests in Normative Power Europe, "Journal of Common Market Studies", 53: 6, pp. 1285-1300.

Matthijs M., McNamara K. (2015), The Euro Crisis'Theory Effect: Northern Saints, Southern Sinners, and the Demise of the Eurobond, "Journal of European Integration", 37:2, pp. 229-245.

Matthijs M., Blyth M. (2015), Introduction: the future of the Euro and the politics of embedded currency areas, in: The future of the Euro, eds. M. Matthijs, M. Blyth, Oxford University Press, New York.

McNamara K. (2015), Forgotten embeddedness: history lessons for the Euro, in: The future of the Euro, eds. M. Matthijs, M. Blyth, Oxford University Press, New York.

Merkel A. (2012), https://www.telegraph.co.uk/finance/financialcrisis/9224465/German-ChancellorAngela-Merkel-defends-austerity-in-face-of-open-rebellion-in-Europe.html.

Schauble W. (2011), Why austerity is only cure for the Eurozone, "Financial Times", September 5, http://www.ft.com/intl/cms/s/0/97b826e2-d7ab-11e0-a06b-00144feabdc0.html\#axzz355 KUI33Z.

Schimmelfennig F. (2014), EU Enlargement and Differentiation: Discrimination or Equal Treatment?, "Journal of European Public Policy", 21: 5, pp. 681-698.

Schulz M. (2015), https://www.reuters.com/article/us-europe-migrants-schulz-idUSKCN0QY0 DQ20150829.

Sedelmeier U. (2008), After conditionality: post-accession compliance with EU law in East Central Europe, "Journal of European Public Policy", 15: 6, pp. 806-825.

Sikorski R. (2011), Poland and the future of the European Union, Berlin, 28 November 2011, https:// mfa.gov.p1/resource/33ce6061-ec12-4da1-a145-01e2995c6302:JCR.

Sikorski R. (2012), https://www.msz.gov.pl/pl/p/msz_pl/polityka_zagraniczna/priorytety_polityki_ zagr_2017_2021/expose2/expose_2012/.

Sikorski R. (2013), Informacja Ministra Spraw Zagranicznych o zadaniach polskiej polityki zagranicznej w 2013 r. (Annual Address of the Minister of Foreign Affairs on the Tasks of Polish Foreign Policy in 2013), 20.03.2013, http://www.msz.gov.pl/pl/aktualnosci/wiadomosci/ informacja_ministra_spraw_zagranicznych_o_zadaniach_polskiej_polityki_zagranicznej_ w_2013_roku.

Szydło (2015), Sprawozdanie stenograficzne z 1 posiedzenia Sejmu Rzeczypospolitej Polskiej VIII Kadencji w dniu 18 listopada (4 dzień obrad), Warszawa 2015, http://orka2.sejm.gov.p1/ StenoInter8.nsf/0/ACC7A0E8310D1F55C1257F01004844EA/\%24File/01_d_ksiazka.pdf.

Szydło (2016a), http://193.200.216.101/en/news/news,496916,terror-acts-in-europe-prove-polandright-in-its-migration-policy---pm.html.

Szydło (2016b), https://dorzeczy.pl/kraj/30477/Mocne-slowa-Szydlo-w-Sejmie-Nie-bedziemyuczestniczyc-w-szalenstwie-brukselskich-elit.html.

Szymański K. (2015a), http://wpolityce.pl/polityka/271409-nasz-wywiad-konrad-szymanski-nowyminister-ds-europejskich-o-imigrantach-roli-berlina-pakiecie-klimatycznym-nord-stream-2tusku-i-wyjasnieniu-1004-polecamy.

Szymański K. (2015b), http://wpolityce.pl/swiat/271757-polska-musi-zachowac-pelna-kontrolenad-swoimi-granicami-nad-polityka-azylowa-i-migracyjna. 
Szymański K. (2018), Jedność Europy nie może być tylko dekoracją, „Polski Przegląd Dyplomatyczny", 2(73).

The Economist (2016), https://www.economist.com/europe/2016/01/28/big-bad-visegrad.

Tusk D. (2011), Sejm RP Kadencja VII, Sprawozdanie stenograficzne z 3 posiedzenia Sejmu RP, 15.12.2011 (drugi dzień obrad), Warszawa 2011, http://orka2.sejm.gov.pl/StenoInter7.nsf/0/ B5BC8CC970FA8E58C125796800473F23/\%24File/3_b_ksiazka.pdf.

Villumsen Berling T. (2012), Bourdieu, International Relations, and European security, "Theory and Society", 41: 5, pp. 451-478.

Waltz K. N. (2010), Theory of International Politics, Waveland Press.

Waszczykowski W. (2016), http://telewizjarepublika.pl/waszczykowski-krytykuje-ke-ws-uchodzcow-w-obliczu-kryzysu-migracyjnego-komisja-europejska-podjela-serie-pospiesznych-nieodpowiedzialnych-i-nieprzemyslanych-krokow,37267.html.

Zarakol A. (2017), Theorizing Hierarchies. An Introduction, in: Hierarchies in World Politics, ed. A. Zarakol, Cambridge University Press, Cambridge.

Zarakol A. (2011), After Defeat: how the East Learned to Live with the West, Cambridge University Press, Cambridge.

Zarycki T., Smoczyński R., Warczok T. (2017), The Roots of Polish Culture-Centered Politics: Toward a Non-Purely Cultural Model of Cultural Domination in Central and Eastern Europe, "East European Politics and Societies and Cultures", 31: 2, pp. 360-381.

\section{Summary}

This article conceptually draws on Bourdieu's field theory and Goffman's stigma theory to explain the evolution of Polish government's official narrative on European integration. Narrative production by Polish authorities reveals a marked shift in strategy adopted to deal with the stigma (real or imagined) that structures Poland's position in the EU field of power: from adaptive (corrective) to contesting strategy where stigma is embraced and transformed into a virtue. Empirically, this shift is illustrated with 3 examples of narrative production under crisis: 1) euro-zone crisis (Poland adapts to the dominant EU narrative and promotes its own austerity experience, while allying itself with the northern "saints" against the southern "sinners"); 2) migration crisis (Poland moves from adaptation to contestation, while narrating the "lack of solidarity" stigma as the responsible "normal"); 3) rule of law crisis (Poland consolidates its contestation strategy, while framing the dispute as a counter-measure from undemocratic EU centre to discipline "real" democrats in the periphery). Thus the narrative moves from contestation of a particular policy solution (migration quotas) to undermining normative bases of the European integration process.

Key words: Poland, European Union, narrative, adaptation, contestation

Od ambitnego świętoszka do rozczarowanego buntownika. Jak wyjaśnić zmianę polskiej narracji o integracji europejskiej

\section{Streszczenie}

W wymiarze koncepcyjnym artykuł czerpie z teorii pola Bourdieu i teorii stygmatyzacji Goffmana w celu wyjaśnienia ewolucji oficjalnej narracji polskiego rządu w odniesieniu do integracji europejskiej. Analiza produkcji narracji przez rząd RP ukazuje znaczące przesunięcie 
w zakresie strategii radzenia sobie ze stygmatyzacją (faktyczną lub wyobrażoną), która określa pozycję Polski w unijnym polu władzy: od strategii adaptacyjnej (korekcyjnej) do strategii kontestacyjnej, gdzie stygmatyzowany atrybut ulega przekształceniu w cnotę. W wymiarze empirycznym owo przesunięcie zilustrowano 3 przykładami produkcji narracji $\mathrm{w}$ warunkach kryzysu: 1) kryzys strefy euro (Polska adaptuje się do dominującej w UE narracji i promuje własne doświadczenie polityki oszczędności, sprzymierzając się ze "świętymi” z Północy przeciwko "grzesznikom" z Południa); 2) kryzys migracyjny (Polska przechodzi od adaptacji do kontestacji, przekształcając stygmatyzowany "brak solidarności” w odpowiedzialną "normalność"); 3) kryzys rządów prawa (Polska konsoliduje strategię kontestacji, konstruując zaistniały konflikt w kategoriach kontrataku niedemokratycznego unijnego centrum na "prawdziwych" demokratów z peryferii UE). Narracja ewoluuje zatem od kontestacji konkretnego rozwiązania politycznego (kwoty migrantów) do podważenia normatywnych podstaw procesu integracji europejskiej.

Słowa kluczowe: Polska, Unia Europejska, narracja, adaptacja, kontestacja 
